\title{
New Regionalism in Post-Soviet Territory: Evolution from Eurasian Economic Community to Eurasian Economic Union
}

\author{
Çağla Gül Yesevi
}

Istanbul Kültür University, Turkey

Email: c.yesevi@iku.edu.tr

\section{Doi:10.5901/mjss.2014.v5n23p1986}

\begin{abstract}
The post-Soviet region has been facing challenges such as ethnic conflicts, regime instabilities, separatism; border disputes, foreign rivalry, neo-imperial policies, security problems, human and drug trafficking, and water and energy tensions. This article examines the new regionalism of Eurasia with the Eurasian Economic Community. The treaty on the establishment of the Eurasian Economic Community was signed on 10 October 2000 and came into effect on 30 May 2001, once it was ratified by all member states. Russia, Belarus, Kazakhstan, Tajikistan, and Kyrgyzstan have been members of the Eurasian Economic Community since it was formed. Armenia, Moldova, and Ukraine have observer status in the Eurasian Economic Community. In this study, the structure, main aims, activities and roles of the Eurasian Economic Community will be examined and the current status and future prospects of the Eurasian Economic Union will be evaluated in light of the crisis in Ukraine.
\end{abstract}

Keywords: The Eurasian Economic Community, the Eurasian Economic Union, regionalism, Russia, Ukraine

\section{Introduction}

It is apparent that today post-Soviet region has been facing some domestic problems as ethnic conflicts, regime instabilities separatism and some international problems as foreign rivalry, neo-imperial policies, security problems, international terrorism, border disputes, human and drug trafficking, water and energy tensions. Molchanov (2012) states that Eurasian regionalism can be defined as complementary and sometimes contradictory processes of the economic, social, political and normative reintegration of several post-communist states that span the Eurasian continent. Regionalism in Eurasia emerged in the early 1990s with the establishment of the Commonwealth of Independent States. The Commonwealth of Independent States has been treated as an instrument of Russian neo-imperial policies. Eurasian regionalism has been regarded mostly as Russian-centered. The Eurasian Economic Community was established with a treaty signed on 10 October 2000. The main aims of the community have been to complete the establishment of a free trade regime, to recognize a unified customs tariff, and a to establish a unified system of non-tariff regulation measures (EurAsEC, 2011).

It is obvious that Eurasia has been Russia-centered since the eigtheenth century, when the Empire stretched from the Baltics to Afghanistan. In 1943, Halford Mackinder suggested that Russian territory was the heartland of Eurasia. The Eurasian region is abundant in natural resources and also has embraced diverse ethnicities and religions (Tsygankov, 2012, 2).

Regionalism can be developed with the establishment of major organizational forms. The early years of the twentyfirst century have witnessed intensification in regionalism across the globe. International organizations have been instrumental in promoting regionalism.

Regionalism is an important phenomenon in the contemporary global economic system. Contemporary regionalism can be manifested in different forms in different regions. Eurasian regionalism differs from other forms of regionalism. The Ukrainian crisis can be considered a rivalry between European and Eurasian regionalism. Ukraine and the European Union had agreed on a deep and comprehensive free trade area in late 2011. The European Commission had announced on 15 May 2013 that the EU-Ukraine Association agreement might be signed at the Eastern Partnership Summit, to be held in November 2013 (Muradov, 2013). The Ukrainian government did not sign the association agreement with the European Union.

The Russian Federation does not consider Ukraine to be a state. Russian President Vladimir Putin stated on 4 April 2008 that most of Ukraine's territory had been a gift from Russia in the 1950s. Moreover, he added that Western Ukraine was part of Eastern Europe, and Eastern Europe belonged to Russia (Blank, 2011, 75-76). 
The members of the Eurasian Economic Community, Belarus and Kazakhstan, do not support the policy of the Russian Federation on backing separatist movements, such as in the 2008 South Ossetia War (Shelest, 2014, p.3).

It is worth noting that although Putin regretted to accept any purpose to reintegrate Soviet successor states, according to a poll conducted by VtSIOM, after the annexation of Crimea, 82 percent of Russian respondents stated that they had begun to see Russia as a super power similar to the former Soviet Union (Felgenhauer, 2014).

\section{The Establishment of the Eurasian Economic Community (EurAsEC)}

Russia, Belarus, and Kazakhstan established the Eurasian Economic Commission (EurAsEC). The EurAsEC is an international economic organization that was envisioned to be a supranational body for regional integration. The main aims of this integration process were the development of the Customs Union and Common Economic Space, the establishment of common external customs and the development of common foreign economic policies, tariffs and price policies (President of Russia Official Site, 2013a; President of Russia Official Site, 2013b)

Belarus, Kazakhstan, Kyrgyzstan, Russia, and Tajikistan have been members of this organization since it was established. Uzbekistan became a member in January 2006, but suspended its membership at the end of 2008. Although Moldova and Ukraine tried to draw close to the European Union, they were granted observer status in EurAsEC in May 2002. The Russian Fedaeration have never abandoned her aims about the reintegration of post- Soviet states. Armenia joined the EurAsEc as an observer in 2003 (President of Russia Official Site, 2013b).

During the Interstate Council meeting on 16 August 2006 in Sochi, the leaders of Russia decided to establish a customs union within the EurAsEC framework. Belarus, Kazakhstan, and the Russian Federation were the initial members of this customs union. They also declared that other EurAsEC member states would be able to take part in the organziation when their economies had improved. In this context, they agreed that the realization of the EurAsEC customs union and common economic space would help the Community become an important organization for regional integration.

\subsection{Structure}

The EurAsEC's main governing bodies are the Interstate Council, the Integration Committee, the Inter-parliamentary Assembly, the EurAsEC Commission of Permanent Representatives, and the Community's Court of Justice (President of Russia Official Site, 2013b).

Table 1. The Structure of the EurAsEC

\begin{tabular}{|c|c|c|c|c|}
\hline Organs & \multicolumn{4}{|c|}{ Roles and Functions } \\
\hline \begin{tabular}{|l|} 
The EurAsEC Interstate \\
Council
\end{tabular} & $\begin{array}{l}\text { Supreme Body of the } \\
\text { EurAsEC }\end{array}$ & $\begin{array}{l}\text { Considering questions about } \\
\text { Community activities }\end{array}$ & Approving resolutions & $\begin{array}{l}\text { Regulating common trade } \\
\text { terms among the parties }\end{array}$ \\
\hline $\begin{array}{l}\text { The Integration } \\
\text { Committee }\end{array}$ & $\begin{array}{l}\text { Analyzing the integration } \\
\text { processes and preparing } \\
\text { proposals for further } \\
\text { integration }\end{array}$ & $\begin{array}{l}\text { Coordinating national legislations of } \\
\text { the parties. } \\
\text { Setting up rules for mutual } \\
\text { relationships between the parties of } \\
\text { the EurAsEC and third party states } \\
\text { or international organizations. } \\
\end{array}$ & $\begin{array}{l}\text { Elaborating and } \\
\text { implementing investment } \\
\text { plans, and economic, social } \\
\text { and other programs. }\end{array}$ & $\begin{array}{l}\text { Coordinating the customs } \\
\text { policy of member states and } \\
\text { third party states. }\end{array}$ \\
\hline $\begin{array}{l}\text { Integration Committee } \\
\text { Secretariat }\end{array}$ & $\begin{array}{l}\text { The Secretary General } \\
\text { directs the Integration } \\
\text { Committee Secretariat }\end{array}$ & $\begin{array}{l}\text { Directing administrative functions of } \\
\text { the Community }\end{array}$ & $\begin{array}{l}\text { Implementing the } \\
\text { organization of work }\end{array}$ & $\begin{array}{l}\text { Providing technical and } \\
\text { informational assistance to } \\
\text { the Interstate Council and the } \\
\text { Integration Committee }\end{array}$ \\
\hline $\begin{array}{l}\text { The EurAsEC } \\
\text { Commission of } \\
\text { Permanent } \\
\text { Representatives }\end{array}$ & $\begin{array}{l}\text { Directing and assisting the } \\
\text { member states' positions } \\
\text { on issues such as } \\
\text { strengthening cooperation. }\end{array}$ & \begin{tabular}{|l|} 
Providing a forum to implement \\
communication between the \\
Community, bodies, institutions and \\
organizations of the Community \\
member states
\end{tabular} & $\begin{array}{l}\text { Reviewing proposals of the } \\
\text { member states }\end{array}$ & Improving integration \\
\hline $\begin{array}{l}\text { The EurAsEC } \\
\text { Interparliamentary } \\
\text { Assembly }\end{array}$ & $\begin{array}{l}\text { Organ of parliamentary } \\
\text { cooperation }\end{array}$ & Coordinating EurAsEC legal policy & $\begin{array}{l}\text { Coordinating legislative } \\
\text { activities of the national } \\
\text { parliaments according to the } \\
\text { goals and objectives of the } \\
\text { EurAsEC. }\end{array}$ & $\begin{array}{l}\text { Ensuring assistance and } \\
\text { creating conditionsto } \\
\text { harmonize internallaws of } \\
\text { member states according to } \\
\text { EurAsEC regulations } \\
\end{array}$ \\
\hline $\begin{array}{l}\text { The Community Court } \\
\text { of Justice }\end{array}$ & $\begin{array}{l}\text { Settling economic disputes } \\
\text { between the Parties. }\end{array}$ & $\begin{array}{l}\text { Settling disputes on matters related } \\
\text { to EurAsEC's bodies. }\end{array}$ & $\begin{array}{l}\text { Dealing with the provisions of } \\
\text { treaties adopted within } \\
\text { EurAsEC. }\end{array}$ & $\begin{array}{l}\text { Settling } \\
\text { EurAsEC Customs Union } \\
\text { disputes. }\end{array}$ \\
\hline
\end{tabular}

Source: EurAsEC, 2011 


\subsection{Decision-making Process and voting system}

The Interstate Council has been regarded as the supreme organ of the EurAsEC. It makes decision on the initiatives, strategies, and roles of the Community, and prospects for the integration process. The Council has made decisions to implement the objectives and purposes of the EurAsEC.

In the decision-making process, the Interstate Council adopts all resolutions by consensus. The Integration Committee resolutions, on the other hand, are adopted with a two-thirds majority. A weighted voting system is used during the financing of meetings of the Community organs and the Commission of Permanent Representatives within the EurAsEC. Thus, the number of votes for each party is regulated according to its contribution to the budget of the Community. As a result of the weighted voting system, the Republic of Belarus has 15 votes, the Republic of Kazakhstan has 15, the Kyrgyz Republic has 7.5, the Russian Federation, has 40, the Republic of Tajikistan has 7.5, and the Republic of Uzbekistan has 15 (Shadikhodjaev, 2008, p. 20).

\section{Benefits and Positive Aspects of the Eurasian Economic Community}

The EurAsEC covers a territory of $20,374 \mathrm{~km}^{2}$ and has vast resources of minerals and raw materials. The countries are major exporters of mineral resources and metals to the global market (EurAsEC, 2011, p. 4). It should therefore be expected that new candidates such as Turkmenistan and Azerbaijan will further strengthen the economic importance of the Community.

Belarus has been in fifth place of Russia's world trade partners and has been in first place among the CIS member states. Bilateral trade reached $\$ 38.6$ billion 2011, \$43.8 billion in 2012, and \$39.7 billion in 2013 (The Voice of Russia, 2014, April 29).

The Eurasian Customs Union introduced a system of rules harmonized with international norms and the World Trade Organization (WTO) regime. It should be noted that the WTO principles prevail over conflicting Eurasian Customs Union provisions (Dragneva, Wolczuk, 2012, p.9).

The decisions of the EurAsEC are binding to the parties. The removal of the internal borders can be considered an important and symbolic success. The Eurasian Custom codes have replaced the domestic legislation of its memberstates (Dragneva, Wolczuk, 2012, p. 9).

\subsection{The Customs Union between Russia, Belarus, and Kazakhstan}

The Customs Union between Russia, Belarus, and Kazakhstan was established on 19 December 2009, in Almaty, Kazakhstan. The first phase of the Customs Union's functioning began on 1 January 2010. A uniform customs tariff was introduced, approved by the leaders of the three states. The Customs Union is based on a common customs territory. The members of this union concurred that there would be no customs duties or economic restrictions within this territory. They decided to abolish protective, anti-dumping and compensatory measures (President of Russia Official Site, 2013a). The formation of the Customs Union has been considered a precursor to Eurasian Economic Union.

The main aim of member states was the protection of their markets against foreign economic powers. Although the aforementioned customs union agreement came in to force between the Russian Federation, Belarus and Kazakhstan in 2010, the preparations and idea behind this structure dated back to the 1990s. The collapse of the Soviet Union and the nation building processes of the ex-Soviet Republics were considered the flourishing of new open markets in the area. However, the establishment of the customs union demonstrates that there have also been reverse dimensions and contradictory demands within these new republics.

While dealing with the supranational aspect of the regime, it should be stated that some decisions of the Customs Union Commission are been made by the qualified majority under a weighted voting system. Russia has 57 percent while Belarus and Kazakhstan have 21.5 percent each (Dragneva, Wolczuk, 2012, p.7). This mechanism has been empowering Russia.

The Eurasian Economic Community aims to establish a common market in transport services. It is important to note that through that Common Transport Space, EurAsEC will be able to achieve free movement of passengers, baggage, cargo and conveyances. Moreover, a harmonized transport-related legislation and common competition rules will be put into effect. (EurAsEC, 2009b). 


\subsection{Ukraine: Rivalry between the EU and the Eurasian Economic Community}

There was an important competition between Russia and the European Union over Ukraine. Russia attempted to convince Ukraine to become a member of the Eurasian Custom Union while also trying to dissuade Ukraine from concluding an Association Agreement with the EU. Eventually, Ukraine preferred to pursue an Association Agreement with the EU. Russian experts have stated that being part of Eurasian Economic Union would have benefited Ukranian GDP growth. In this context, if Ukraine had chosen to be part of EurAsEC, it would have elevated its GDP from 165 billion dollars to 219 billion dollars between 2011 and 2030. Moreover, the EurAsEC would have helped Ukraine maintain access to Russian markets, especially agricultural products. Despite the EU Association Agreement, advocates of the EurAsEC stated that some of Ukrainian agricultural products would have been subjected to quotas. It was also pointed out that this Deep and Comprehensive Free Trade Area (DCFTA) would jeopardize Ukraine's aviation and shipbuilding industries and agricultural sectors. Russian arguments have also emphasized the protectionist stance of the EU during negotiations of the DCFTA and the uncompetitive nature of Ukrainian goods on the EU Market. Moreover, Russia would have ensured reduced gas prices for Ukraine if it had joined EurAsEC (Dragneva, Wolczuk, 2012).

\subsection{Security of External Borders}

Russia, Belarus, Kazakhstan, Kyrgyzstan, and Tajikistan agreed that they had to cooperate in defense and the protection of the external borders of the parties. They signed a treaty on 21 February 2003on cooperation to protect the external borders of the member states of the Eurasian Economic Community. According to this treaty, the cooperation areas are religious extremism, illegal migration, terrorism, illegal transit of weapons, drugs trafficking and smuggling (EurAsEC, 2009c).

When the countries signed the treaty, they guaranteed their own borders as well as those of the EurAsEC members. The EurAsEC cannot be regarded as an instrument for economic cooperation. When the treaty was signed, the Eurasian Economic Community members also decided to cooperate on security issues. The parties that signed carried out a constant exchange of information on the situation at their external borders (EurAsEC, 2009b).

\section{The Road from the Eurasian Economic Community to the Eurasian Economic Union}

The leaders of Russia, Kazakhstan, and Belarus signed a treaty to establish the Eurasian Economic Union (EaEU) on 29 May 2014. It was planned for the EaEU to be established officially in January 2015, after the treaty was ratified by the countries' respective parliaments. The EaEU aims to provide the free movement of trade, capital, and workers between Russia, Kazakhstan, and Belarus (Felgenhauer, 2014). Russian President Putin stated that the EaEU would work according to international law and the principles of the WTO (President of Russia, 2014b).

Adomeit (2012) posits that one of the major purposes of the Eurasian project is related to Russia's ambitious relationship with the EU on Eurasia. Another purpose of the project could be an attempt to maintain Russian hegemony in Central Asia against the Chinese presence in this region. The EaEU has been an important initiative to reintegrate newly independent states. It is worth noting that, as Putin stated, the territory of the EaEU has had 20 percent of global natural gas reserves and 15 percent of oil reserves (President of Russia, 2014a).

The European Union has been considered a reference of modernization and good governance. It has developed its relations with newly independent states in the context of the European Neighborhood policy, and the Eastern Partnership. Russia has been relying on its energy potential and military power while dealing with the Soviet successor states. It has been relying on an institutional, rule-based regime through the EurAsEC. The Association Agreement of the EU, on the other hand, serves as an important alternative to the post-Soviet states (Dragneva, Wolczuk, 2012, p. 9).

\subsection{Problems of the Regime}

There have been problems in the establishment of the Eurasian Economic Union and the institutionalization of other entities, namely the Customs Union and the Eurasian Economic Community. This regime has been acquiring many different agreements. As Dragneva and Wolczuk (2012) state, these agreements have been complex, fragmented, and contradictory, and difficult to interpret and apply. The main problems behind the Customs Union are the ongoing negotiations and disputes over protectionism, and oil and gas export taxes (Saivetz, 2012, p. 406). Moreover, there has been no agreement on the abolition of multiple tariff and non-tariff barriers, which hinder the free movement of Kazakhstani products into the Russian and Belarussian markets. There have been barriers on construction equipment, 
alcoholic beverages, tobacco, medicine, and most importantly, oil and gas (Voloshin, 2014).

The supranational features of the EurAsEC are considered to be weak. Due to its intergovernmental features, there have been limited commitments from the member states. Most importantly, while the court and central bank are supranational bodies, the decisions are made and implemented by national bureaucracies and political systems. There is no system of checks and balances (Libman, 2011, p. 36).

Dragneva and Wolczuk (2014) state that the Customs Union has had no legal personality. It is considered as an institutionalized treaty regime within the framework of the Eurasian Economic Community. The Customs Union does not have rules to regulate the markets of its members as the European Union does. There are different membership categories. Kyrgyzstan has been planning to join only the Customs Union (Dragneva, Wolczuk, 2014). Russia, Kazakhstan and Belarus have been considering a road map to Armenia's accession to the Customs Union. However, it should be noted that the president of Belarus Lukashenko stated that these three parties, namely Russia, Kazakhstan and Belarus have not accomplished a full-fledged customs union yet (President of the Republic of Belarus, 2014).

Joining to the Eurasian Economic Community is a difficult task. Mainly, accession can be accomplished by signing numerous treaties establishing the Customs Union and the Single Economic Space. Russia, Kazakhstan and Belarus have been working on the official draft of the Eurasian Economic Union. This draft treaty is significant because it stipulates that the Eurasian Economic Union would incorporate the Customs Union. The Eurasian Economic Community will also be disbanded according to the draft treaty. It should be noted that the Eurasian Economic Union will be institutionalized as an intergovernmental international organization in comparison to European supranational institutions. In that sense, bilateral relations have been more powerful than multilateral arrangements (Dragneva, Wolczuk, 2014).

The establishment of the Eurasian Economic Commission as a supranational organ could challenge the sovereignty of Belarus and Kazakhstan. Both countries declared that they were not interested in a deeper political union, which represented loss of their sovereignty (Atılgan, et al., 2014, p. 16).

It is important to note that the parties have agreed on the common gas and oil markets, and that they will be operational until 2025 (President of the Republic of Belarus, 2014). It is worth noting that the economies of Belarus, Kazakhstan, and Russia do not complement each other. The main problem is that these three economies have been competing (Atılgan, et al., 2014, p. 13).

\subsection{Russia and the Eurasian Economic Community}

Russia, Belarus, Kazakhstan, Kyrgyzstan, Tajikistan, and Uzbekistan attended the meeting of the Interstate Council of the Eurasian Economic Community on 12 May 2011. Putin stated that an agreement should be signed on the creation of a Eurasian Economic Union by 1 January 2013. Late in 2011, he called for a stronger "Eurasian Union" that would include Belarus and Kazakhstan initially, and Ukraine, Kyrgyzstan, and Tajikistan later (Spechler and Spechler, 2013).

Putin described the dissolution of the Soviet Union as the biggest geopolitical disaster of the twentieth century (Atilgan, et al., 2014). On 4 October 2011, in an article in Izvestia, he said that the foundation of Russia's policies would be the new integration project for Eurasia. He also mentioned that an economic union should be created depending on the Customs Union and the Single Economic Space. With the foundation of the Eurasian Union, they set the ambitious goal of reaching the next level of integration. He emphasized that Kyrgzstan and Tajikistan would be included in the Customs Union and the Single Economic Space.

It is important to note that Putin stated that the Eurasian Union, like the European Union, would rest on four pillars, the free movement of goods, capital and labor, common economic and monetary policy, and the establishment of supranational organization. These would extend further to the political entity (Adomeit, 2012).

Putin stressed that on 19 September 2013 this Eurasian integration would be an opportunity for the former Soviet Republics to become the independent center of global development rather than being on the periphery of Europe or Asia (Atilgan, et al., 2014, p. 13). After signing the treaty to establish the Eurasian Economic Union (the EaEU), he said that the EaEU would not be harmful to the sovereignty of its member states. Among other benefits, energy, agriculture, transport, and industry policies would be coordinated. Armenia and Kyrgyzstan also would eventually become members. This union should have free trade agreements with Vietnam, Israel, and India and strong cooperation with China (Felgenhauer, 2014). (Ria Novosti, 2014).

\subsection{Belarus and the Eurasian Economic Community}

Belarus has always had a significant role in Russia's geostrategic relations with NATO. As an important transit country for Russia, it provides road and rail connections to Kaliningrad, and transports Russian oil and gas to the European market. 
Belarus and Russia have been partners in many organizations, such as the Constitutional Union of Russia-Belarus, the $\mathrm{CIS}$, the EurAsEC, the Customs Union and the Single Economic Space (SES), and the Collective Security Treaty Organization. Russia has always influenced Belarusian policies. The main concerns in this relationship have been the dependence of the Lukashenko regime on the issues of energy, trade, and the economy, and the Russian Federation.

Belarus obtains all of its gas needs and 90 percent of its oil needs from Russia. Adomeit (2012) writes that there is a link between Russia's subsidization of Belarus and Putin's Eurasian regionalism. As the Russian premier made clear, the discounts in natural gas prices were related to the integration process itself. Russia has been giving financial assistance to Belarus. Collaborations such as the Customs Union, Single Economic Space, and the Eurasian Union project have had both economic and political rationales. As Trenin (2011) states, the EurAsEc has been a political platform for economic integration.

Belarus joined the union because it was experiencing economic problems. It needed loans and discounted prices for oil and gas. EurAsEc has already given Belarus $\$ 800$ million and will give an additional $\$ 2.2$ billion within next two years. These economic subsidies and loans will reduce Belarus's sovereignty (Saivetz, 2012, p. 406). Belarus has been paying \$165 per thousand cubic meters of gas. Belarussian trade with Kazakhstan only amounts to 1 percent of Belarus' total trade volume. Eighty percent of the Belarussian economy is dominated by state companies. Russia and Armenia became World Trade Organization members. It can be argued that cheap oil and gas could hamper the efforts to improve the Belarussian economy.

Gas prices in Armenia declined from $\$ 270$ to $\$ 189$. In return for these prices, Russia demanded a 20 percent share of ArmRusgasprom (Atılgan, et al., 2014, pp. 35-43). Lukashenka has been insisting that Russia permit Belarussian refineries to buy large amounts of crude oil from Russia duty free and to export Belarussian products to Western countries. However, Russia has been pressing Belarus on trade quotas and tax payments to constrain the depletion of the Belarussian budget (Felgenhauer, 2014).

In relation to the Ukrainian crisis, Lukashenko has not referred to the new Ukrainian government of Turchnynov as "Kyiv junta," as the Russians have (loffe, 2014b). Belarus has been using methods similar to those of Ukraine, maneuvering between the Russia-led Customs Union and the EU. It has been searching for more subsidization on energy prices and has been emphasizing the Belarussian identity, seeing as Lukashenko did not want to convert Belarus into Eastern Ukraine (Ioffe, 2014a).

President Lukashenka stated, after signing a treaty to establish the Eurasian Economic Union, that the union would not solve all of the existing trade problems. He said the union would be a good forum for social, political, and military integration. However, the EaEU has had economic goals as well. He said he viewed the union as an instrument for further integration, similar to Russia (Felgenhauer, 2014).

\subsection{Kazakhstan and Eurasian Economic Community}

The idea of the EaEU initially came from Nursultan Nazarbaev, president of Kazakhstan. The country has always emphasized that regional organization would be in the form of economic integration. Russia also has been interested in a political union. Nazarbaev strongly believes that democratic change could be attained by strong economic growth. Kazakhstan's share of revenues within the Eurasian Customs Union was 17 percent in 2011, but fell to 17 percent in 2012. While imports from Russia and Belarus increased by 12 percent, Kazakhstan's exports declined by 3.7 percent in 2012. Moreover, Kazakhstan's small and medium-sized enterprises were affected severly by tariffs imposed on nonmember states.

Kazakstan's economy is under the influence of external events. Its position in the Eurasian Economic Union has been affected by the crisis in Ukraine. It has been following Russia's foreign policy carefully since the events. Moreover, some of its economic sectors, especially chemicals and agriculture, compete against Russian companies (Cohen, 2013). Another important factor is the growing influence of China on the country, especially in the energy sector (Atilgan, et al., 2014, pp. 19-23).

A common external tariff imposed by Kazakhstan led to an increase in imports from Russia and a decline in imports from Europe. The displacement of European goods resulted in market hegemony with lower quality Russian imports at higher prices coming (Tarr, 2012, p. 3). According to World Bank 2011 estimates, Kazakhstan's tariffs increased from 6.7 percent to 11.1 percent on an unweighted basis after the country entered the Customs Union. In this context, it experienced losses in income, wages, and return of capital after its accession to the Customs Union (Carneiro, 2013 , p. 2)

Kazakhstan has been deeply concerned about the US and EU sanctions imposed on Russia after its annexation of Crimea. The sanctions have affected Kazakhstan's economy. Thirty-six percent of Kazakhstan's imports are from 
Russian while 7 percent of its exports go to Russia. According to an EBRD report, remittance flows and exports have weakened. The report also states that the exacerbation of the Ukrainian crises could lead to economic decline in Central Asian economies. Kazakhstan has been aiming to preserve its financial independence; however, Russian and Chinese influence could hamper this aim (Dally, 2014).

\subsection{Ukraine and the Eurasian Economic Community}

Russia attempted to put pressure on Ukraine, having demanded that Ukraine be part of the EurAsEC (Saivetz, 2012, p. 406). Minister Tatiana Volovaja, board member of the Eurasian Economic Commission, said that Ukrainian membership was seen as an important contribution to the Eurasian Economic Community. She stated that there could be no successful regional integration without Ukraine (Atilgan, et al., 2014, p. 17).

Armenia fulfilled all of the requirements of the EU about signing the Association Agreement in 2010. However, in September 2013, the Armenian government declared that they would be part of the Eurasian Customs Union (Rettman, 2013). Ukraine could have followed the same route. The EU declared that they would finance Ukrainian economic reforms, but refused to pay Ukrainian debt. After the Association Agreement was signed, the EU promised to finance Ukraine with 20 billion euros from the IMF. In return for this payment, the EU demanded that Ukraine raise its gas prices and devalue its currency. On 17 December 2013, Russia agreed to give Ukraine 15 billion dollars financial aid (Atilgan, et al., 2014, pp. 25-28).

Ukrainian President Victor Yanukovich said that Ukrainian constitution barred the country from from joining supranational organizations, including the Eurasian Economic Union (Kyiv Post, 2012b). Ukrainian Prime Minister Mykola Azarov announced that Ukraine was considering cooperative relations with both the EU and the EurAsEC (Kyivpost, 2012a). Ukraine was granted observer status in the EurAsEC in May 2013.

Despite these developments, it was clear Ukrainian relations with the EurAsEC member states were troubled. Russia, for example, had banned some Ukrainian goods; for example, cheese. On its part, Ukraine had constricting shipments of some Belarussian and Russian products. Russia threatened to regulate gas prices, which had been expensive, but said it would improve prices if Ukraine joined the Customs Union. It also offered to discount gas rates if Gazprom were allowed to control Ukrainian gas pipelines, which transport gas to Europe. After having had observer status in the EurAsEC, Yanucovich stated that these the member countries would not jeopardize Ukraine's plans for deals with the EU (Reuters, 2013).

According to a survey by the Democratic Initiative Foundation, 72.5 percent of the respondents in western Ukraine and 48.5 percent of the respondents in central Ukraine support joining the EU. However, 53.7 percent of the respondents in southern Ukraine and 60 percent of the respondents in eastern Ukraine demanded to join to the Eurasian Customs Union (Atılgan, et al., 2014, p. 25).

The EU plan of creating a Deep and Comprehensive Free Trade Area (DCFTA) offered Ukraine a gradual reduction of export tariffs. The DCFTA would improve institutions, welfare benefits, and the reduction of capital costs. Moreover, it would propose new possibilities for Ukrainian products in EU markets (Shumylo-Tapiola, 2014, pp. 6-8).

After signing a treaty to establish the Eurasian Economic Union on 29 May 2014, the Russian First Deputy Prime Minister, Igor Shuvalov, declared that the establishment of the EaEU would not be affected by the Ukrainian crisis, which he maintained was a local and internal crisis. He stated that the Ukrainians should decide for themselves with whom they wanted to be in this world.

\subsection{Armenia and the Eurasian Economic Community}

Armenian President Serzh Sarkisian declared that Armenia's accession treaty would be signed before 15 June 2014, and Armenia would join the EaEU in January 2015. Armenian workers had been working and living in Russia. Being part of the EaEU would be beneficial for them. Moreover, Armenia could expect to be more powerful economically and politically with assistance of its big brother, Russia. In this context, this membership would strengthen the Armenian position over the disputed Karabakh territory (Felgenhauer, 2014).

\section{Conclusion}

The main aims of the Eurasian Economic Community have been to complete the formalization of a free trade regime, to create a unified customs tariff, and a unified system of non-tariff regulation measures. The Russian Federation, Belarus, and Kazakhstan founded a Customs Union on 1 January 2010, and have been enjoying a Single Economic Space since 
1 January 2012. They have plans to create a Eurasian Union by 2015. Eurasian regionalism can be considered a complementary yet sometimes contradictory process of economic, social, political, and normative reintegration of several post-communist states that span the Eurasian continent.

Eurasian regionalism has been regarded mostly as Russian-centered. It should be noted that the member-states' main aim was the protection of their markets against foreign economic powers. The member-states play a leading role among exporting countries with regard to oil and gas, chrome, manganese resources, aluminum, nickel, copper and raw diamonds. It should therefore be expected that new candidates such as Tajikistan and Kyrgyzstan and, in the future, Turkmenistan and Azerbaijan, would further strengthen the economic importance of the Community.

Belarus is dependent on the Russian economy and benefits from Russian financial assistance. Kazakhstan has been in favor of strengthening economic integration with the EurAsEC rather than the political integration demanded by Russia. It is anxious about increasing imports from Russia and decreasing those from Europe.

The Eurasian Economic Community members cooperate on security issues, having signed a treaty on cooperation for the protection of the borders of the member states of the Eurasian Economic Community on 21 February 2003. In this context, EurAsEc is a political platform for economic integration. It could be regarded as a tool of Russian hegemony for further re-integration in post-Soviet territory. The Customs Union, the EurAsEC, and the Eurasian Economic Union have the potential to make Russia a more powerful regional actor with the potential to control even the internal affairs of member-states. The Eurasian Economic Union will be an important step for the Russian Federation to reintegrate Soviet successor states and strengthen Eurasian regionalism, both economically and politically. The establishment of common gas and oil market would further strengthen the Eurasian Economic Union.

\section{References}

Adomeit, H. (2012). Putin's Eurasian Union: Russia's Integration Project and Policies on Post-Soviet Space. Neighbourhood Policy Paper. Kadir Has University CIES. 1-13.

Atllgan, C, Bauman, G, Brakel, A., Crawfor, C., Devcic, J., Helms, A. (2014). The Eurasian Union: An Integration Process under the Microscope. KAS International Reports.

Blank, S. (2012). Sovereignity and Democracy in Eurasia. (pp.75-95). In Stephen Blank (Ed.) Perspectives on Russian Foreign Policy. Carlisle: Strategic Security Institution.

Carneiro, F.G. (2013, February). What Promises does the Eurasian Customs Union Hold for the Future? The World Bank, 108.

Cohen, A. (2013, June 25). Ryssia2s Eurasian Union could endanger the Neighborhood and the US interests. Valdai Discussion Club. Retrieved from http://valdaiclub.com/russia_and_the_world/59580.html (May 25, 2014).

Dally, J. C. K. (2014, May 21). Kazakhstan Nervously Contemplates Possible Impact of Sanctions Against Russia. Eurasia Daily Monitor 11(95). Retrieved from http://www.jamestown.org/single/?tx_ttnews\%5Bswords\%5D=8fd5893941d69d0be3f378576261ae3e \&tx_ttnews\%5Bany_of_the_words\%5D=eurasian\%20economic\%20community\&tx_ttnews\%5Btt_news\%5D=42405\&tx_ttews\%5 BbackPid\%5D=7\&cHash=c3ebd1396a33c32bb8db59739f3f2c32\#.U4HWs1KKAqQ (May 25, 2014).

Dragneva, R., Wolczuk, K. (2014, February 3). The Eurasian Customs Union and Ukraine. Global Policy Journal. Retrieved from http://www.globalpolicyjournal.com/blog/03/02/2014/eurasian-customs-union-and-ukraine (May 20, 2014).

Dragneva, R., Wolczuk, K. (2012, August). Russia, the Eurasian Customs Union and the EU: Cooperation, Stagnation or Rivalry? London: Chatham House.

EurAsEC Official Site. (2013a). About EurAsEC. Retrieved from http://www.evrazes.com/en/about/ (May 25, 2013).

EurAsEC (2011). EurAsEC Today. Retrieved from http://www.evrazes.com/en/about/ (May 25, 2013).

EurAsEC Official Site. (2009a). Interstate Council Resolution 23 May 2000. Retrieved from http://www.evrazes.com/docs/view/92 (May 26, 2013).

EurAsEC Official Site. (2009b). Concept of Establishment of the Common Transport Space of the Eurasian Economic Community, 25 February 2008. Retrieved from http://www.evrazes.com/docs/view/156 (May 26, 2013).

EurAsEC Official Site. (2009c). On cooperation in protection of external borders on cooperation in protection of external borders of the member states of the Eurasian Economic Community on 21 February 2003. Retrieved from http://www.evrazes.com/docs/ view/137 (May 24, 2013).

EurAsEC Official Site. (2009d). Treaty on the Establishment of the Eurasian Economic Community amended on 25 January 2006 and 6 October 2007 Retrieved from http://www.evrazes.com/docs/view/95 (May 25, 2013).

Farrell, M. (2005). The Global Politics of Regionalism: An Introduction. In M. Farrell and B. Hattne (Eds.), Global Politics of Regionalism: Theory and Practice. 1-17. Sidmouth: Pluto Press.

Felgenhauer, P. (2014, May 29). Russia, Kazakhstan and Belarus Form Eurasian Economic Union. Eurasia Daily Monitor, 11(100). Retrieved from http://app.bronto.com/public/?q=preview_message\&fn=Link\&t=1\&ssid=500\&id=k708y68uehjx5v61 xp11/1w fvbzlt\&id2=0340operk83g3al0j|wtcyvkzmdas\&subscriber_id=bprksjffmopwfsgkanflwybzuwnjbib\&messageversion_id=agghkuxazp kdqdxjwlieuvampwaubim\&delivery_id=bzrbssrykprkxtfafmixzsghgwnobim\&tid=3.AfQ.CDFfGw.CwXB.AU7XIQ..ArqeOA.b.I.AxTh.b .U4e9FA.U4e9FA.SK-41A (May 30, 2014).

Ioffe, G. (2014a, May 14). Lukashenka's New Victory and a fight for Belarussian Identity. Eurasian Daily Monitor 11(90). Retrieved from 
http://www.jamestown.org/single/?tx_ttnews\%5Bswords\%5D=8fd5893941d69d0be3f378576261ae3e\&tx_ttnews\%5Bany_of_the _ words\%5D=eurasian\%20economic\%20community\&tx_ttnews\%5Bpointer\%5D=1\&tx_ttnews\%5Btt_news\%5D=42361\&tx_ttnews \%5BbackPid\%5D=7\&cHash=b56128d662858c3fa162effbe4c90ed07\#.U4HUiVKKAqQ (May 25, 2014).

Ioffe, G. (2014b, May 9). The Prospective Eurasian Treaty and Lukashenko's Loyalties. Eurasian Daily Monitor 11(87). Retrieved from http://www.jamestown.org/single/?tx_ttnews\%5Bswords\%5D=8fd5893941d69d0be3f378576261ae3e\&tx_ttnews\%5Bany_of_the_ words\%5D=eurasian\%20economic\%20community\&tx_ttnews\%5Bpointer\%5D=2\&tx_ttnews\%5Btt_news $\% 5 \mathrm{D}=42346 \& t x \_t$ tnews \%5BbackPid\%5D=7\&cHash=c9fb5a5e8db219114d9481bf7360fdc0\#.U4HXn1KKAqQ (May 25,2014).

Kyiv Post (2012a, December 17). Azarov: Ukraine could cooperate with Customs Union and EU. Retrieved from http://www.kyivpost. com/content/ukraine/azarov-ukraine-could-cooperate-with-customs-union-and-eu-317740.html (May 25, 2014).

Kyiv Post (2012b, March 21). Yanukovych : Ukraine's constitution does not allow entry into Customs Union. Retrieved from http://www.kyivpost.com/content/ukraine/yanukovych-ukraines-constitution-does-not-allow-en-124683.html (May 25 2014).

Libman, A. (2011). Commonwealth of Independent States and Eurasian Economic Community. In Giovanni Finizio, Lucio Levi, Nicola Vallinota (Eds.) Democratization of International Organizations. Moncalieri: International Democracy Watch.

Molchanov, M. A. (2012). Eurasian Regionalisms and Russian Foreign Policy. UACES Convention Exchanging Ideas on Europe 2012 , 3-5 September 2012. Passau, Germany.

Muradov, K. (2013, September 17). Russia's Pivot to Eurasia and the battle for Ukraine. East Asia Forum. Retrieved from http://www.eastasiaforum.org/2013/09/17/russias-pivot-to-eurasia-and-the-battle-for-ukraine/ (May 21, 2014).

President of Belarus Official Site. (2014, April 29). Meeting of the Supreme Eurasian Economic Council. Retrieved from http://president.gov.by/en/news_en/view/meeting-of-the-supreme-eurasian-economic-council-8625/ (May 20, 2014).

President of Russia Official Site. (2014a, May 29). Speech at Supreme Eurasian Economic Council Meeting in narrow format. Retrieved from http://eng.kremlin.ru/transcripts/22403 (May 30, 2014).

President of Russia Official Site. (2014b, May 29). Press Statement Following the Supreme Eurasian Economic Council Meeting. Retrieved from http://eng.kremlin.ru/transcripts/22404 (May 30, 2014).

President of Russia Official Site. (2013a). Glossary: C Retrieved from http://eng.news.kremlin.ru/terms/C\#term_28. (May 27, 2013).

President of Russia Official Site. (2013b). Glossary: E Retriewed from http://eng.news.kremlin.ru/terms/E (May 25, 2013).

Rettman, A. (2013, September 3). Armenia to join Russia trade bloc, surprises EU. Euobserver . Retrieved from http://euobserver.com /foreign/121304 (May 25, 2014).

Reuters. (2013, May 31). Ukraine to be observer in Russia-led Trade Bloc. Retrieved from http://uk.reuters.com/article/2013/05/31/ukukraine-russia-trade-idUKBRE94U0UK20130531 (May 24, 2014).

Ria Novosti (2014, May 29). Transferring Powers to Eurasian Union Does Not Harm Sovereignty - Putin. Retrieved from http://en.ria.ru/world/20140529/190216402/Transferring-Powers-to-Eurasian-Union-Does-Not-Harm-Sovereignty-.html (May 30, 2014).

Saivetz, C.R. (2012). The Ties that bind? Russia's Evolving Relations with its Neighbors. Communist and Post-Communities Studies 45 , 401-412.

Shadikhodjaev, S. (2008). EurAsEC: Legal Aspects of Regional Trade Integration. Seoul: KIEP.

Shelest, H. (2014, March 12). Ukraine: The Revolution of Minds?. CIES Commentary. Istanbul: Kadir Has University.

Shumylo-Tapiola, O. (2012, April). Ukraine at the Crossroads: Between the EU DCFTA \& Customs Union. Russia . NEI Reports,11. Paris: Russi/NIS Center.

Spechler, M.C. and Spechler D.R. (2013). Russia's lost position in Central Eurasia. Journal of Eurasian Studies 4, 1-7.

Tarr, D.G. (2012, December 5). The Eurasian Customs Union among Russia, Belarus, and Kazakhstan: Can it succeed Where its predecessor failed? Retrieved from http://papers.ssrn.com/sol3/papers.cfm?abstract_id=2185517 (May 25, 2014).

Tsygankov, A. P. (2012). The Heartland no More: Russia's Weakness and Eurasian Meltdown. Journal of Eurasian Studies 3, 1-9.

Vipisauskas, R., Alisauskas, R. (2012). Eurasian Union: A Challenge for the EU and Eastern Partnership Countries. Vilnius: Eastern European Studies Centre.

Voice of Russia (2014, April). All principal disagreements on Eurasian Economic Union draft treaty settled - chairman. Retrieved from http://voiceofrussia.com/news/2014_04_29/All-principal-disagreements-on-Eurasian-Economic-Union-draft-treatysettled-chairman-2581/ (May 20, 2014).

Voloshin, G. (2014, May 9). Kazakhstan prepares to sign Eurasian Union Treaty Despite Lingering Problems. Eurasia Daily Monitor 11(87). Retrieved from http://www.jamestown.org/single/?tx_ttnews\%5Bswords\%5D= 8fd5893941d69d0be3f378576261ae3e \&tx_ttnews\%5Bany_of_the_words\%5D=eurasian\%20economic\%20community\&tx_ttnews\%5Bpointer\%5D=2\&tx_ttnews\%5Btt_n ews\%5D=42345\&tx_ttnews\%5BbackPid\%5D=7\&cHash=400ab1ebb8667d30739ff3c7518b0a17\#.U4Ha_VKKAqQ (May $\overline{25}$, 2014). 